\title{
Space Engineering
}

\section{宇宙工学部門ニュースレターNo.2 1 日本機械学会}

†160-0016 東京都新宿区信濃町 35 番地 信濃町棟瓦館 5 階
January 2007
TEL. 03-5360-3500
FAX. 03-5360-3508
ホームページアドレス
www. isme. or. ip / sed

\section{第 14 回衛星設計コンテスト開催}

\section{ブルージェットを知っていますか?}

日本機械学会宇宙工学部門表彰フロンティアの部には東 北大学大学院から提案された「LAISIN」が選ばれました。

「LAISIN」は Lightning and Atmospheric electricity phenomena In Storms Investigator から命名された衛星で す。この衛星は、その名の音（雷神）が示すように台風の 中で発生する雷や台風の上空に出現するブルージェットを 観測する衛星です。ブルージェットとは、台風から上空に 向けて立ち上がる高高度発光現像であり、定量的な観測デ 一タはほとんどありません。また、大洋上の台風の中で発 生する雷を定常的に観測することも行われていません。こ れらの自然現象の観測を行ら衛星は今までになく、発生期 から最盛期にかけての台風の構造変化を研究する上で、高 い成果が期待されます。この衛星の提案チームは、工学研 究科と理学研究科の院生達の混成であり、お互いの持ち味 を生かしたユニークな衛星を提案しました。衛星は作る時 代から使う時代に変わりましたが、若手の新鮮なアイデア は衛星の無限の利用方法があることを教えてくれました。 彼らの今後の発展に期待します。

サクラソウ、ミジンコ泳いで、アリ社会 衛星設計コンテストの優秀作品を紹介いたします。設計 大賞に輝いたのは、日本大学大学院が提案する「PRIMROSE」 です。衛星から伸展する 4 本のインフレータブルチューブ の展開実験と、その間に張られた膜のエアロブレーキ効果 を利用した高度変更実験を行う衛星です。地上実験を見せ てのプレゼンは聴衆に実現性の高さを与えてくれました。 サクラソウ (primrose) が宇宙で花咲くことを期待します。 アイデア大賞は、鳥羽商船高専の「宇宙旅行で心を癒す 「ミジンコが棲む小さな地球」へ授与されました。宇宙旅 行する人々へ「癒し」を与えようといら発想が創ったミジ ンコのホッピング運動を実現させる地球型水槽です。電気 誘導で擬似重力をミジンコに与えようとするアイデアは、 きれいなアクリル模型とともに聴衆の関心を集めました。

ジュニア部門賞は、山口県立厚狭高校の「宇宙での生活 が動物社会へ与える影響」が獲りました。スペースコロニ 一などの微小重力や狭小空間で恒久的に生活する人々は、 ストレスが体内の生理機能に影響が及ぶだけでなく、社会 構造にも影響が及ぶことが危惧されます。それにアリを用 いて実験しようとする提案です。どのような社会が形成さ いられるか大変興味がある提案でした。

\section{百聞は一見にしかず。}

優劣をつけがたいプレゼンテーションの中で、話題を呼 んだのはミジンコの電気誘導実験のビデオでした。地上の 重力があるので、お世辞にも癒されるとは言い難いビデオ でした。電極に引き寄せられるミジンコの身になればアリ 地獄へ落ちていく時のような恐怖感があったでしょう。で も、それでいいのです。荒削りな実験でも、人にモノを見 せれば納得してもらえます。話題にしてもらえます。設計 大賞も実現性のある地上実験ビデオを紹介しました。若い 力を見習って、宇宙の話題を盛り上げるモノを作りましょ う。そして、彼らの衛星を打上げる流れを作りましょう。

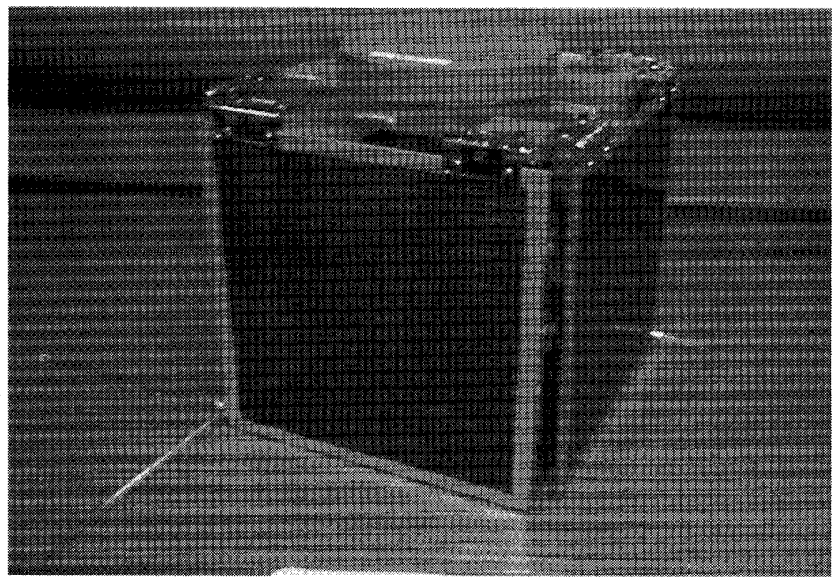

写真 1 日本機械学会宇宙工学部門賞を受賞した $\lceil$ LAISIN 」

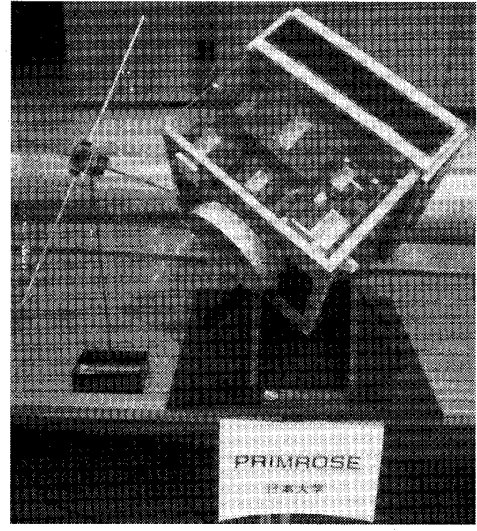

写真 2 TPRIMROSE

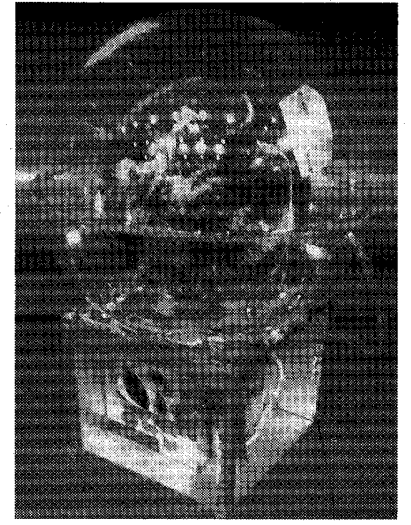

写真 3 「ミジンコが棲む 小さな地球」 


\section{$M-V 7$ 号機打ち上げ}

東京工業大学 機械宇宙学科 4 年生 松永研究室 芦田 宏樹

2006 年 9 月 23 日 06 時 36 分、世界最大の全段固体口ケ ット M-V の最終機となる $M-V-7$ 号機が、その先端に太陽観 測衛星”ひので”を載せて、鹿児島県肝付町の内之浦宇宙 空間観測所から打ち上げられました。幸運にもその見学に 行く機会に恵まれた私が実際に見たこと、そして感じたこ とを、観望記として記します。

1992 年、まだ私が小学生だったときに、毛利衛さんがス ペースシャトルエンデバーで宇宙飛行をされて以来、私は ずっと宇宙に憧れてきました。特にロケットが好きな私に とっては、M-V 最後の打ち上げを見学できるなど、まるで 夢のようでした。

22 日昼の便で、羽田から 2 時間弱で鹿児島へ。鹿児島空 港で足となるレンタカーを借り、鹿児島駅で先生をピック アップ、21 時台のフェリーで桜島へ。このフェリーが第 13 桜島丸で、”Sakurajima 13” は問題なく目的地に着ける だろうかと、先輩と圥談を飛ばしていました。桜島はちょ うど噴火が報じられていた頃で、夕方は対岸からでもかす かに噴煙が上がっているのが見えました。

桜島からは、途中鹿屋で休颕を取りつつ、夜道をひたす ら内之浦へ。日付が変わろうかという頃に内之浦に到着し、 コスモピアのロビーで 1 時間ほどの仮眠を取り、いよいよ 内之浦宇宙空間観測所へ移動。まずは管理センタ内の会議 室に入りました。そこにはISAS の全ての衛星に対して、関 係者の方々がサインをした色紙が展示されており、ISASの 歴史の流れを感じることのできるものでした。

他にも、 $34 \mathrm{~m}$ パラボラアンテナや、コントロールセンタ 脇から整備塔を見たりして回りましたが、一部を除いて、 打ち上げが迫っているとは分からないような闇と静寂が支 配する世界。

そうして見学しているうちに、見学場所へ移動する時間 となり、見学者が続々と管理センタ前に集まってきました。 ところが、バスを待っている間に雨が降りだしてしまいま す。しかもかなり雨脚が強く、嫌でも頭をよぎるのは M-V8 号機。あの時は我々の研究室で作った衛星、Cute-1.7+APD* も搭載してありましたが、打ち上げ間近に雨で 1 日順延と なりました。

雨があがり始めた頃、管理センタ前からバスに乗り、見 学場所一移動。舗装された道を10分ほど行くと、警察官が 交通整理をしているところがありました。そこを脇道に入 り、夜の闇の中、車1台分ほどの幅しかない山道を数分バス に摇られて、新宮原レーダーセンタに到着。そこには打ち 上げ時にロケットを追跡、テレメータのダウンリンクをす

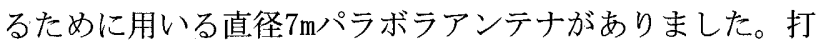
ち上げ数時間後に、それが高速で動いているのを目撃、あ の速度ならロケットの追尾も可能だなと納得。

新宮原から整備塔までは数 $\mathrm{km}_{\text {。 }}$ 間に障害となるものはな いのでM-Vの姿がはっきりと見えます。目と鼻の先にあると 思えるような7号機は、あまりにも静かに佇んでいて、とて も数時間後には爆音を轟かせながら宇宙へと飛んでいくと は思えません。周りから聞こえるのは見学者の雑談、強風 の吹き荒ぶ音、そして唯一打ち上げが間近であることを教 えてくれるカウントダウンのアナウンス。

打ち上げ5分前頃から、見学者達の様子が変わりました。
見学所全体が緊張に包まれ、雑談の声が消えて行きます。 そして打ち上げ15秒前、M-Vの油圧系駆動のためのタービン を回す小さな黒い煙が出ているのが見えます。ここまで来 たら中止はないはず。「ああ、本当に打ち上がるんだ」と、 頭ではようやく理解できたものの、周りは相変わらず風の 音だけで、実感が湧きません。

ついにカウントゼロで第1段モータに点火し、美しい閃光 を放ちながらランチャから離れる $M-V$ 。 しかし、2km以上離 れた宮原には音が 10 秒弱遅れて届くので、まったく音はし ません。風の音と歓声の中を、M-Vが静かに、しかし勢いよ く駆け上がって行く様に、とても不思議な感覚を覚えまし た。

そして遅れて、全身を震わせるような音がやってきま す。”音”といらよりは、”振動”。漫画などでよく”バ リバリ”という擬音語が用いられますが、まさにそう表す しかないような音でした。打ち上げ後十数秒で、M-V本体は 低く垂れ込めていた雲に隠れてしまいましたが、その音は しばらく聞こえていました。私は、音が聞こえた瞬間から、 あまりの感動に足の震えが止まらず、その震えは打ち上げ 後10分以上経っても収まりませんでした。

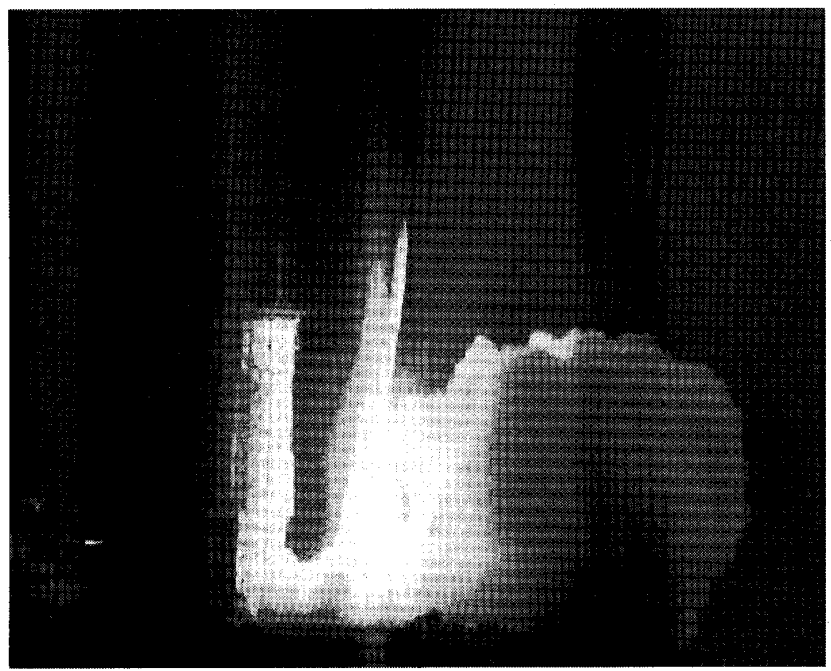

写真 1 発射台を離れるM-V-7号機

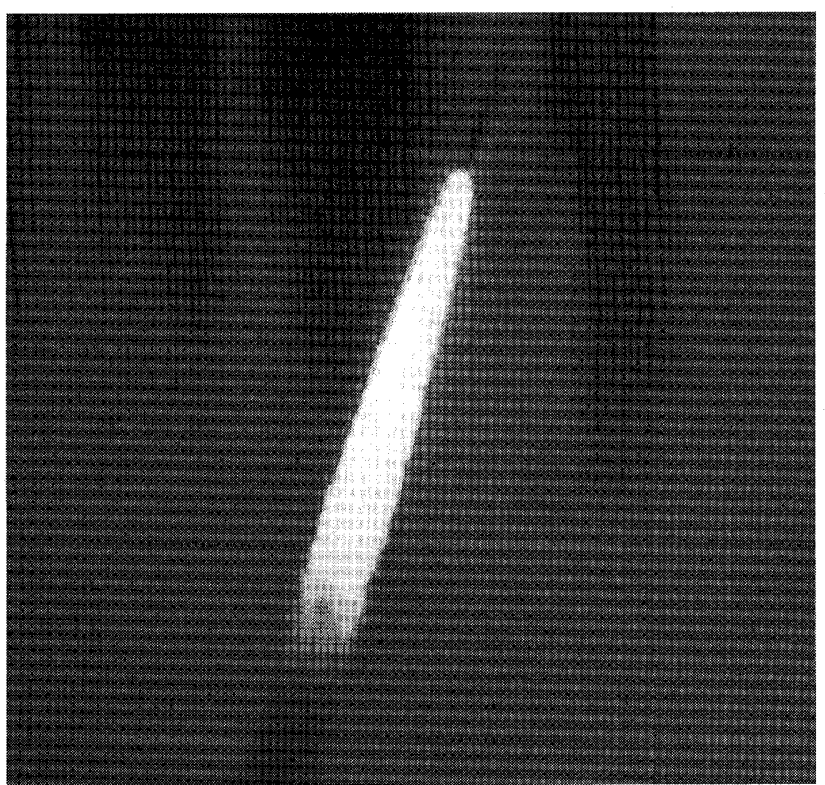

写真 2 爆音を轟かせ力強く上昇する $\mathrm{M}-\mathrm{V}-7$ 号機 
打ち上げ後しばらくして、宮原から道路を見下ろすと、 山間の道には似つかわしくない大涉滞が起きていました。 たくさんの方々が一緒にM-Vの打ち上げを見に来て、同じ感 動を共有していたのだと感じ、一宇宙ファンとして非常に 嬉しくなりました。

内之浦の管理センタに戻ると、ISAS恒例の色紙書きが始 まっていました。そこにいらっしやるのは川口先生、小杉 先生、的川先生、森田先生ら、本でお名前を扭見するよう な先生方ばかり。直接お目にかかることができ、私は嬉し さを通り過ぎて半ば混乱状態でした。

その後、研究室の0Bの方々に観測所内の各所を案内して いただきました。

まずは、Mロケットの整備塔。遠くから見るとなかなかそ の実感できないのですが、真下から見るとその巨大さに压 倒されます。中に格納されていたランチャは、黒く焼け焦 げていたり、熱でゆがんでいたり。ロケットの打ち上げ時 の環境の凄まじさを感じました。整備塔の屋上に登らせて いただき、周りを見回すと、内之浦がいかに自然と同居し ているかが分かります。故系川先生は、よくぞこんなに起 伏に富んだところにロケットの射場を造ろうと思われたな と感じました。

次に、饴地の地下にある発射管制室も見学させていただ きました。誰もいない、しかし微かに緊張感が残っている ような管制室で、静かに佇む機器を見回しながら、わずか 数時閒前にあった、素晴らしい打ち上げに思いを馳せまし た。

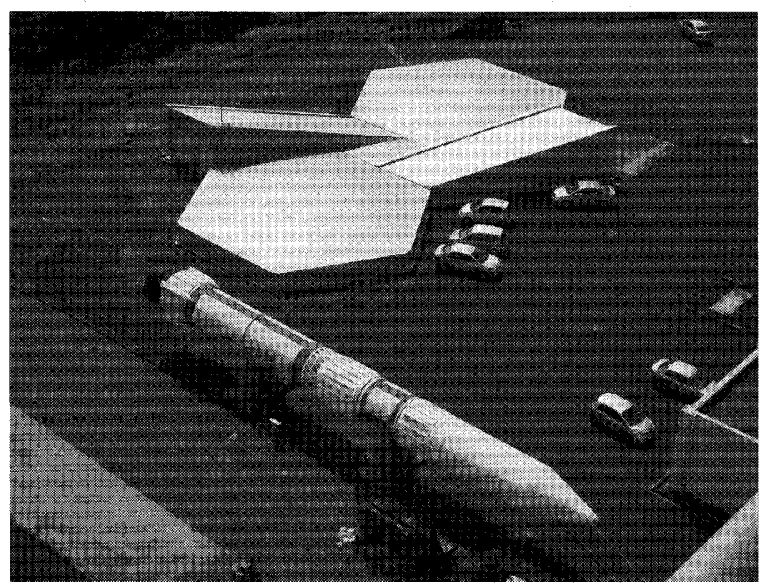

写真 3 整備塔屋上から見たM-V-1モデルと発射管制棟

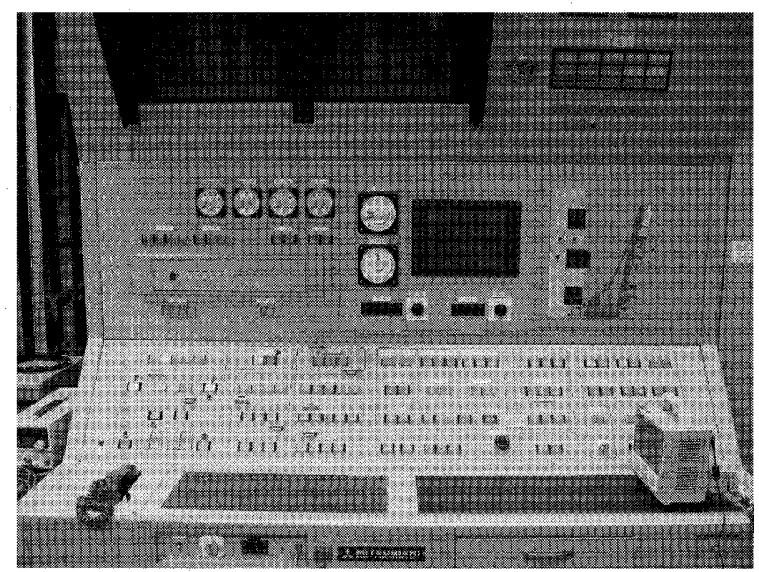

写真 4 発射管制室のランチャーコントローラ
その他にも初期運用中の衛星テレメータセンタや、打ち 上げをモニタするラジオセンタ、コントロールセンタなど を見学させていただきましたが、その全てが興味深いもの で、とても充実した、楽しい時間を過ごさせていただきま した。

観測所からの帰りは昼で、行きと違って日が明るかった ので、行きには見ることのできなかった、内之浦の色々な ところを見ることができました。小学校の壁画や、橋や公 民館、至るところに宇宙やロケットをモチーフにしたもの があり、普通は一般の方々にはあまり馴染多のない”宇宙” というものが、内之浦においては地元に密着していること を感じました。なにより、帰りに立ち寄った鹿児島中央駅 の肉まん屋の、ごく普通のおばちやんが、M-Vや、ラムダの ことを当たり前のように知っていたことは驚きでした。東 京ではあの” はやぶさ”すらご存知でない方が多いことに 対して、内之浦でISASが長い時間をかけて築いてきたもの を垣間見た気がしました。未だに、M-Vが退役し、内之浦廃 止論が取り沙汰されているとは信じられません。

初めて行った内之浦は、自然と住民、そしてロケットす ベてが見事に一体となった、素晴らしいところでした。ま た美しいロケットの打ち上げを見に行きたいと強く感じま す。

\footnotetext{
${ }^{*}$ Cute $-1.7+$ APD : 東京工業大学松永研究室が開発した超 小型衛星。
}

http://1ss. mes. titech. ac. jp/ssp/cute1. 7

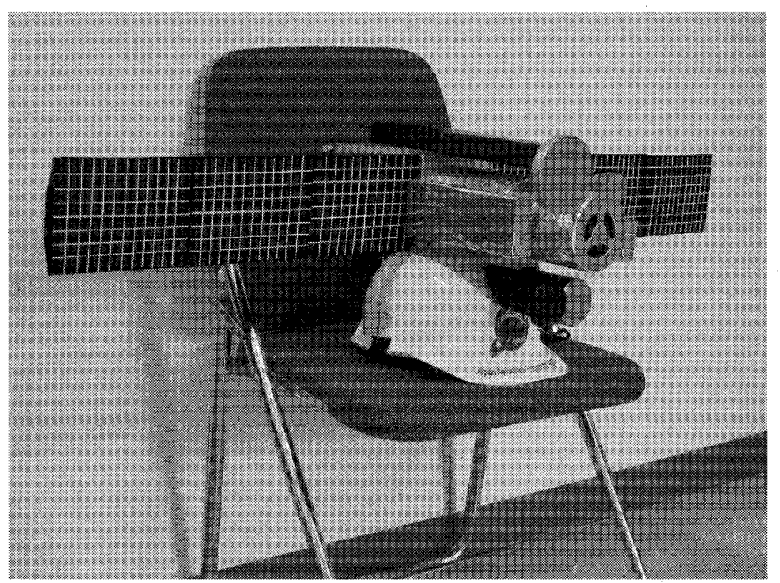

$$
\text { 写真 } 5 \text { 成功祈願 (?) のヘルメット }
$$

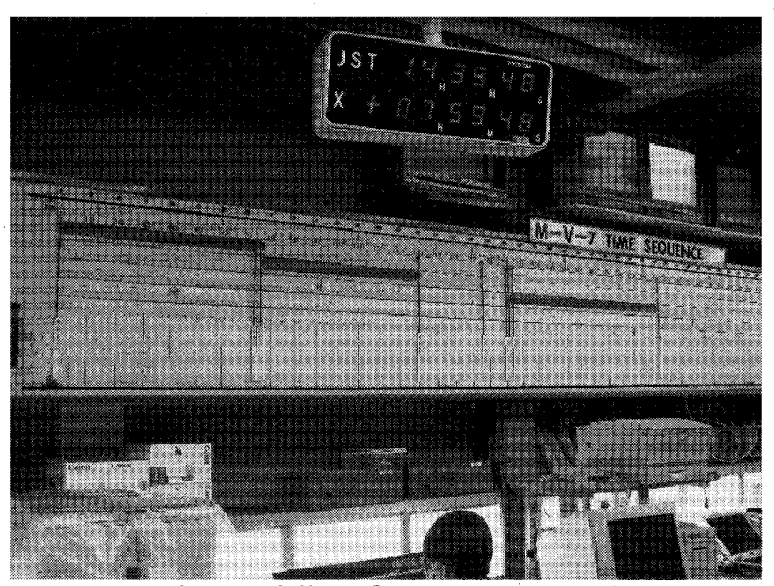

写真 6 時代を感じるシーケンス盤 


\section{大学衛星 : 2006 年は 3 機打ち上げ！}

\section{日本の数kg級超小型衛星とCute-1. 7 + APD \\ 東京工業大学 松永 三郎}

超小型衛星は、衛星開発の全過程を体験する実践的な宇 宙システム工学教育を実施でき、また、プロジェクトマネ ジメントの面でも極めて有効な教育手段として注目されて います。さらに、先端的な宇宙理工学技術を1.5-2年のサイ クルで早期に複数回、軌道実証できる手段として、そして、 一般市民にも宇宙を身近に感じてもらえるような新しい宇 宙ビジネスの舞台として、新しい宇宙開発を切り開く可能 性も有望視されています。日本では2003年6月30日に東大・ 中須賀研、東工大・松永研がそれぞれ開発した $10 \mathrm{~cm}$ 角・ $1 \mathrm{~kg}$ の超小型衛星XI-IV, CUTE-Iがロシアのロケットにより打ち 上げられ、軌道上運用に成功しました。1 kg級でも衛星機能 を実現できることを世界で初めて実証し、3年を経過した現 在でも問題なく動作を続けています。この衛星は送受信機 能もつ衛星としては世界最小であり、学生主導開発の民間 衛星で、しかも詳細情報をwebにて全世界に公開していると 言う点で極めてユニークな衛星です。

図 1 は今までの日本の超小型衛星に関連する打上実績を まとめました。2003年の打上後、2005年7月に東工大が日本 のM-V-6ロケットによる超小型衛星用の分離機構実証 (TSD) に成功して、M-V次号機以降の超小型衛星打ち上げの道を切 り開き、11月に東大がESAの衛星とともに前号機バックアッ プを改良したXI-Vをロシア Cosmosで打ち上げ、現在も運用 しています。2006年2月には、東工大が、理学系研究室と協 力して、理工学実証衛星Cute-1.7+APDをM-V-8で打ち上げ、 2 ケ月閒の運用に成功しました。7月には日大・宮崎研の SEEDSが、2年の待機を経てロシアDneprにて打ち上げられま した（不幸にもロケット自身が失敗）。続く9月には北海道 グループのHITSAT、ISAS/JAXAのSSSATがM-V-7にて打ち上げ に成功しました。このように、ここ数年で数 $\mathrm{kg}$ 級超小型衛 星を7機打ち上げ、世界をリードしています。

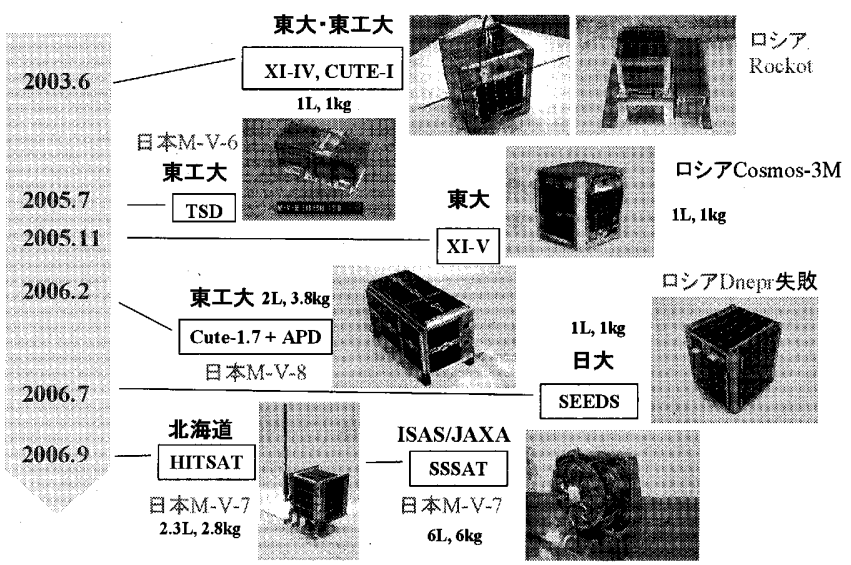

図 1 日本の数 $k g$ 級超小型衛星の実績（7機の打ち上げ）

本特集では、特に、大学主導で開発され、2006年に打ち 上げられた3機の衛星について簡単に紹介します。

まず、Cute-1.7 + APD は、東工大松永研究室によって開 発された第 2 番目の超小型衛星です。本衛星は JAXA/ISAS の M-V8 号機サブペイロードとして公募選定され、平成 18 年 2 月 22 日 (水) 午前 6 -時 28 分、赤外線天文観測衛星「あ かり」とともに、近地点高度約 $310 \mathrm{~km}$ 、遠地点高度約 $735 \mathrm{~km}$ 、 軌道傾斜角 98.2 度の概太陽同期軌道に打ら上げられまし た。 $10 \mathrm{~cm} \times 10 \mathrm{~cm} \times 20 \mathrm{~cm}$ の小容積、質量 $3.6 \mathrm{~kg}$ （軌道寿命延 長のため重量化）と小粒ですが、多種多様な理工学ミッシ ヨンを実施するために高集積多機能を有する衛星です。
主なミッションは、1 ) PDAなどの民生品を用いて宇宙環 境下での動作を保障した衛星バス機器の軌道上実証、2) 基礎物理学専攻河合研究室の超小型高性能APD (Avalanche Photo Diode) センサの軌道上実証と低エネルギー (10-30keV) 荷電粒子の計測、3）世界中のアマチュア無線 家へのアマチュア無線サービスの提供、4）3 軸姿勢決定 と磁気トルカを用いた制御実験の遂行、5）超小型テザー 伸展機構の軌道上実証、6）超小型衛星用分離機構システ 厶の軌道上実証、など多岐に渡ります。特に、APDは放射線 検出器として初めて軌道上実証を行い、次世代 $\gamma$ 線天文衛 星への搭載を目指しました。

打ち上げ後、APDセンサの基本機能、2台のPDA、USB入出 力などの基本バス機器の機能を確認し、約2ヶ月の運用を行 いました。現在、衛星は残念ながら受信用コンピュータ素 子の放射線障害による不具合を被り、現在、復旧中となり ましたが、世界中のアマチュア無線家数百局以上から受信 報告を受け、国際宇宙機関であるAMSATから2機の東工大衛 星にCUBESAT OSCAR (C0-55, C0-56) の称号が付与されまし た（後日、東大衛星にもC0-57, C0-58が付与）。

もともと投入軌道高度が低く、初期には軌道寿命がせい ぜい数ヶ月程度と予想されていたので、2号機の打ち上げ機 会を並行して探り、カナダのトロント大学UTIASの仲介で、 インドのロケットPSLVにより、2007年夏に打ち上げる覚書 を3月に交わしました。現在、1号機の軌道上運用結果を踏 まえた改良 2 号機のFM開発を精力的に行っており、次回はす べてのミッションを成功裏に実施したいと願っています。

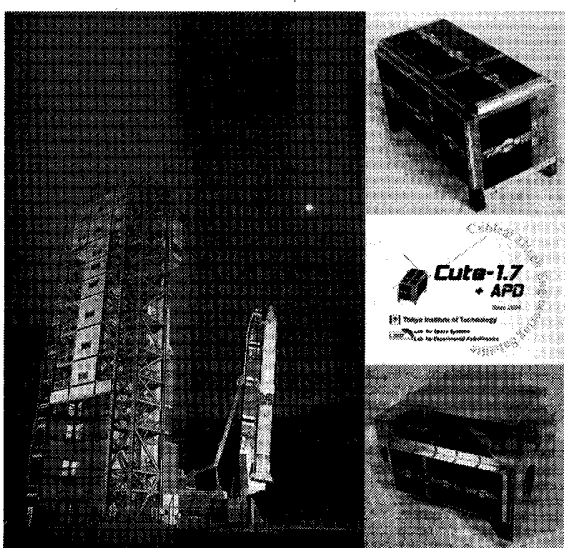

図 2 月夜のM-V8 とCute-1.7+ APD (右下は分離機構付)

日本大学 SEEDS

日本大学 宮崎 康行

日本大学理工学部航空宇宙工学科では、学生有志が開発 した、SEEDS (シーズ) と名付けた CubeSat $(10 \mathrm{~cm}$ 立方で $1 \mathrm{~kg}$ の超小型人工衛星）を、ロシアの Kosmotras 社のドニ エプルロケットを用いて、バイコヌール宇宙基地より平成 18 年 7 月 26 日（木） 4 時 43 分（現地時間の 1 時 43 分）に 打ち上げた。ベラルーシ・ロシア・イタリアの計 4 個の衛 星と、米国・ノルウェー・韓国の 13 機の CubeSat と合わせ、 合計 18 機の衛星のクラスタ打上げであった。当初の予定で は高度約 $600 \mathrm{~km}$ の太陽同期軌道に投入される予定であった が、打上げ直後に 1 段エンジンの配管の一部が過熱し、エ ンジンが緊急停止したために、打上げの約 74 秒後に、打上 げ地点から約 $150 \mathrm{~km}$ 南の地点に落下し、打上げは失敗に終 わった。SEEDS の打上げは当初は2004 年秋を予定していた が、主衛星の開発の遅れや、最終的には主衛星の変更を経 
て、ようやく打上げが叶っただけに、大変残念であった。

今回の打上げでは、100 名をゆうに越える（大型バス 3 台分の) 衛星関係者が 7 月 25 日にモスクワからチャーター 機でバイコヌールに入り (CubeSat 関係者については 1 大 学につき 2 名以下という制限があった。このあたりは、打 ち上げ費用の負担率に依存するのであろう)、26 日現地 の見学をし、ミーティングを経て、27 日未明の打上げに望 んだ。1つの CubeSatを除く 17 機の衛星については、その 一部、またはほぼ全てが学生の主導で開発され、学生の教 育を衛星開発の目的の一つとしていたこともあって、衛星 関係者の多くは学生であった。

我々衛星関係者は、打上げ地点から約 $7 \mathrm{~km}$ 離れた、小さ な小屋があるだけの見学地点で打上げを見守っていた。打 上げ前には現場で飲み物や軽食をとり、お互いの衛星につ いて語り合ったり、テレビ局の取材にロシアの学生が答え たり寸る風景が見られるなど、楽しい雰囲気であった。そ して、打上げ時には大きな（黄色い?）歓声が上がった。

打上げから数十分経った後、現場で Kosmotras 社の責任 者がコメントを発表し、その時点でロケットの失敗が明ら かになった。彼の発した”failure”の一言に現場が凍り付 いたあの状況、特に、それまで半ばお祭り気分?で打上げ に参加していたヨーロッパの学生達のすすり泣きや悲しみ に満ちた表情は、一生忘れることはできないであろう。と 同時に、1 回の打上げに非常に広範囲の関係者が携わるこ とになるクラスタ打上げというものの怖さも痛感した。

その後、関係者はホテルに戻り、朝の全体ミーティング で状況を確認しただけで、そのままモスクワにチャーター 機で戻って解散した。

今回の打上げでは、我々は SEEDS に保険をかけておらず (保険が高額なため)、また、ロケット側・衛星側はお互い に賠償責任を問わない旨の覚書を交わしていたため、その 後、金銭的な問題は発生していない。

この失敗を受け、我々は SEEDS の予備機の打上げ準備に 入った。そして、来年夏にインドの PSLVロケットで打ち上 げる機会を得ることができ、8 月中に覚書を交わした。現 在、予備機の調整および法的手続きを進めている。失敗か ら 1 年足らずで打上げることができるといらのは極めて幸 運である。今回のロケット失敗に関して、多くの方々から 暖かい励ましの誩葉をいただいた。その方々のお気持ち にこたえるためにも、来年の打上げは是非成功させたい。

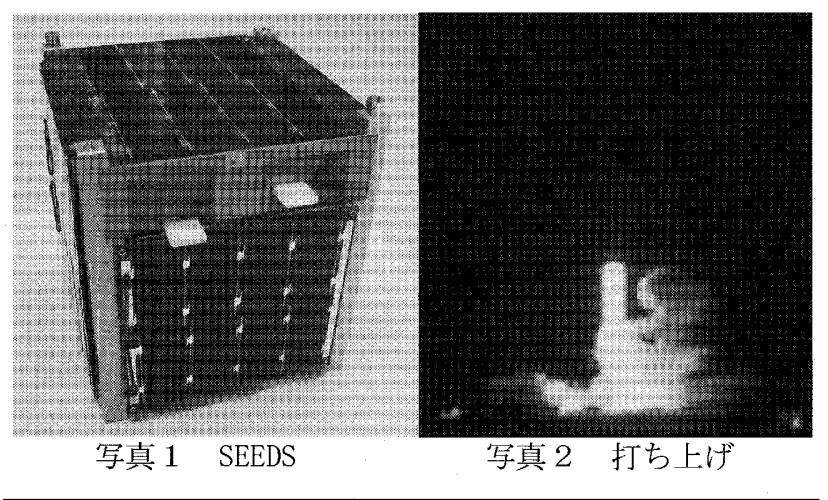

HIT-SAT 開発物語

北海道工業大学 佐鳥 新

重量 $2.7 \mathrm{~kg}$ 、大きさが $12 \mathrm{~cm} \times 12 \mathrm{~cm} \times 12 \mathrm{~cm}$ といら非常に小 さいものの、しかし、北海道初の超小型人工衛星『HIT-SAT (ヒット・サット)』の開発は平成 17 年 4 月末頃に $M-V$ ロケ
ット 7 号機に重量 $5 \mathrm{~kg}$ 以内のサブペイロード (相乗り衛星) を募集に採択された時から北海道工業大学 (道工大) ・北海 道大学の学生を含む約 20 名のメンバーによりスタートし ました。

当然ですが宇宙開発の現場では学生だからという甘充は 通用しません。 $M-V$ 搭載が決定したとき、私は会議の冒頭 で「自信のない人は今回は辞退して欲しい。」言いました。 学生とはいえハイブリッドロケットで空缶衛星（カンサッ ト）を打ち上げた経験のあるメンバーだけあって、私の言 葉に怯む人はいませんでした。これが HIT-SAT 開発のキッ ク・オフでした。HIT-SAT の通信系を含む回路全般及び地 上局を道工大が、姿勢制御系と熱・構造設計および分離機構 の開発を北大が担当することになりました。

最初に作ったのがブレッド・ボード・モデル (BBM) といっ て、人工衛星と同一の機能を持つ模型でした。BBM では電 子基板やセンサー類をテーブルの上に全部並ベ、パソコン から送ったコマンドで設計通り作動するかどうかを評価し ました。設計会議では午前 10 時から夜 11 時過ぎまで激論 が続きました。

次は技術モデル (EM) といって、12 cm 立方の構体に収め たモデルを製作しました。回路設計や基板設計も製品並み の品質が要求されます。EMからはロケットの打ち上げ環境 試験（ランダム振動試験、低周波衝撃試験、高周波衝撃試 験）で壞れないことが審査基準となります。道工大で製作 した回路基板を夕力に北大一持ち込んで徹夜で衛星構体に 組み込み、翌朝には道立工業試験場で約 $20 \mathrm{G}$ の加速度でガ タガタと強烈な振動を加えます。コネクタの剥離など回路 の破損などもあり、その度に品質管理と組み立て作業の工 程管理のチェック体制が改善されました。開発メンバーは 研究室に週 5〜6 日は泊り込んで頑張りました。

平成 18 年 4 月からは相模原の JAXA 宇宙科学研究本部で ロケットとの噛み合わせ試験が 3 週間にわたり実施されま した。フライトモデル (FM) の開発からは衛星の組み立て 及び試験は全てクリーンルーム内で行うことになりました。 FM の全動作確認試験と運用プログラムの実装作業は第 2 組 オペと呼ばれる射場作業の直前まで続きました。赤平の植 松電機で HIT-SAT の真空試験を実施し、先発隊が 9 月 3 日 にFM を内之浦宇宙空間観測所一搬入しました。

そして平成18年9月 23 日に内之浦から定刻通りにM-V(ミ ュー・ファイブ)ロケットが打ち上げられました。主衛星分 離後の6時50分に宇宙空間に放出され、日本時間7時42分に HIT-SATからのCW（モールス信号によるコールサイン）を受 信したという第一報がフロ リダのアマチュア無線家か ら入りました。15時36分に は道工大の地上局でも HIT-SATからの強いCW信号 を受信しました。AMSATから はアマチュア無線の世界で は特別な意味を持つ「59」 の付いた「H0-59」を付与さ れ、国際的にもアマチュア 無線衛星として正式に認可 されました。僅か $2.7 \mathrm{~kg}$ の小 さな衛星ですが、HIT-SAT の成功は北海道新聞のトッ プ記事に取り上げられ、道 民に大きな夢と希望を提供 することができました。

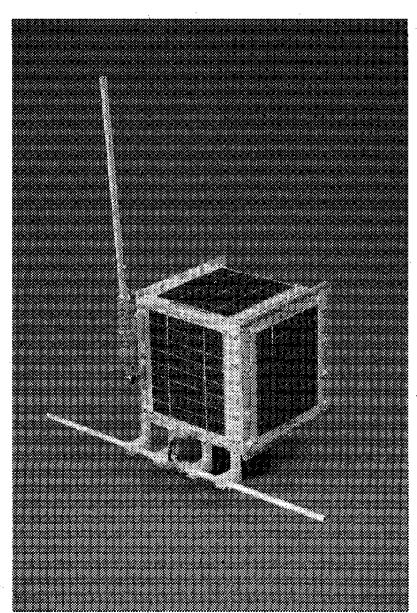

写真3 HIT-SAT 


\section{宇宙旅行の動向と展望}

\section{三菱スペース・ソフトウエア（株） 横井 貴弘 \\ 1.はじめに \\ 旅行会社から一般向けの宇宙旅行 (以下、宇宙旅行) が 発売されるようになった。これにより、一般の人が宇宙旅 行を楽しめる時代が到来しようとしている。 \\ 技術的な観点からいえば、有人宇宙飛行は 40 年以上もの 実績を積み上げてきた技術である。ではなぜ今、宇宙旅行 が現実味を帯びてきたのか、そしてこれからの宇宙旅行は どのようになるのか。 \\ ここでは宇宙旅行の状況と技術、今後の事業の展望を考 察する。}

\section{2. 宇宙旅行の害現}

2.1. デニス・チトー氏とスペースアドベンチャーズ社

最初に宇宙旅行を実現したのはアメリカの実業家、デニ ス・チトー氏であった。彼の功績は宇宙旅行をしたという 事実ではなく、何も無い状態から宇宙旅行という道筋を作 ったことにあるだろう。

チトー氏は当初、ロシアの宇宙ステーション・ミールに 滞在する計画を立てていた。だが実現前にミールプロジェ クトが終了となり、彼の夢は頓挫したかに見えた。しかし その後、スペースアドベンチャーズ社と協力して様々な困 難を乗り越え、2001 年 4 月 28 日、ソユーズ・ロケットで 宇宙に上がり、国際宇宙ステーション（写真 1 ）に 5 日間 滞在した。

彼は後に宇宙旅行実現の困難を本の中でこう象徴的に語 っている。“信じてもらいたいのですが、小切手を書くのは 私にとって一番簡単なパートでした”*1と。

しかし、この宇宙旅行は既存の宇宙開発機関ミッション との相乗りで、事業としては宇宙開発機関からは独立して いなかった。そして費用は $\$ 20,000,000$ と桁外れで、とて も一般向けとは呼べなかった。

この宇宙旅行はその費用にも関わらず申込者は後を絶た ず、2006 年 11 月現在、 4 人の旅行者を宇宙に送り出してい る。

\section{このツアーは現在実現している唯一の宇宙旅行である。}

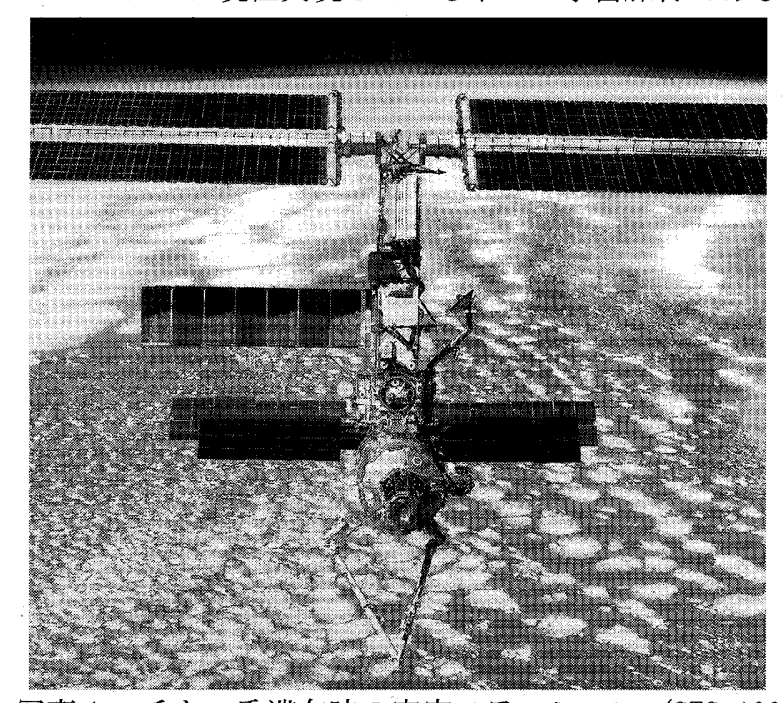

写真 1 チトー氏滞在時の宇宙ステーション (STS-100)

(写真提供 : NASA) $\frac{2 \text { 2. ア アンサリXプライズとスケールコンポジット社 }}{\text { 次に宇宙旅行実現に向けて変化を促したのは } 1997 \text { 年に }}$ 発表された X プライズ財団企画の「アンサリXプライズ」 だった。これは民間資金により 3 人乗り宇宙船を 2 週間以 内に同じ機体で 2 回、高度 100 キロを達成する宇宙船の開 発を競うものであった。これにより民間宇宙機のハードウ エア開発が大きく加速された。世界各国からは 20 を超え る団体が挑戦をした。ちなみに日本から挑戦団体はなかっ た。

この賞に、バート・ルータン氏率いるスケールコンポジ ット社のスペースシップワンが挑戦し、第 1 回目の飛行を 2004 年 9 月 29 日に、 2 度目の宇宙飛行を 10 月 4 日に成功 させた。これはマスコミでも大きく取り上げられたのでご 存知の方も多いだろう。(写真 2)

この宇宙船の製造および飛行は完全に民間資金でまかな われて㧍り、飛行成功後、パイロットは “Government Zero (政府支援無し)”の看板を大きく揭げた。

この宇宙飛行成功を受けて、アメリカ連邦航空局 (FAA) はパイロットに民間宇宙飛行士の徽章を贈っている。ここ に、民間宇宙パイロットも誕生した。

現在、スペースコンポジット社はヴァージンギャラクテ イック社と提携し、事業用宇宙機を開発中である。こちら の宇宙旅行はまもなく開始される見込みである。

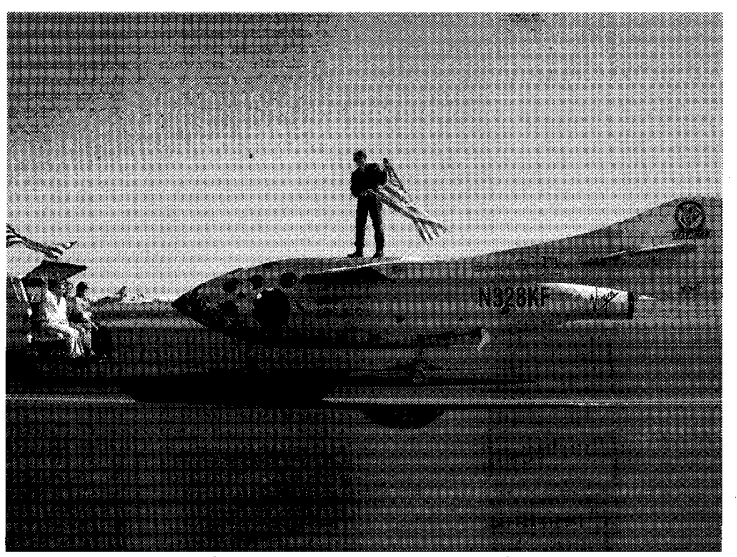

写真 2 スペースシップワン

(写真提供 : ヴァージン ギャラクティック社)

\section{3. 法の道筋}

宇宙旅行事業化に向けて状況を大きく変化させたのは規 制緩和だった。2004 年 12 月にアメリカのブッシュ大統領 は宇宙旅行の一般化を推し進める上で規制緩和を発表。連 邦航空局 (FAA) による認可も一般の航空事業に比べかなり 簡略化され、アメリカ運輸省も数年内の事業認可を表明。 宇宙旅行事業が民間で実現できるようになった。

ちなみに、ブッシュ大統領が商業宇宙旅行を推し進める 法案にサインした時には宇宙旅行者は寸でに 2 人存在して おり、さらにスペースシップワンがアンサリX プライズを 受賞して宇宙旅行が現実味を帯びた後である。

残念ながら日本ではまだ商業宇宙旅行に関する法律は存 在しない。日本人が海外の宇宙旅行プログラムに参加する のは多分良いだるう。しかし、日本で宇宙旅行を事業化す るにはまず法を整備する必要がある。 


\section{3. 宇宙機開発の展望}

実験機ではスペースシップワンが一番乗りを果たしたが、 事業用機ではまだ各社挽回のチャンスがある。

アンサリXプライズの競争と実験機による宇宙飛行が成 功したことで、現在多くのベンチャーが事業用の宇宙機開 発を本格化させている。かつて自動車や航空機産業の草創 期がそうであったように、各社が想像力を駆使し、独自の アイデアで宇宙機を開発中である。

最初の開発ターダットは弾道宇宙旅行用の宇宙機の開発 となる。弾道飛行の宇宙旅行とは、砲弾のような軌道で宇 宙に飛び出し、約 5 分程の無重量状態を体験し、地球の眺 めを楽しむものである。(写真 3 )

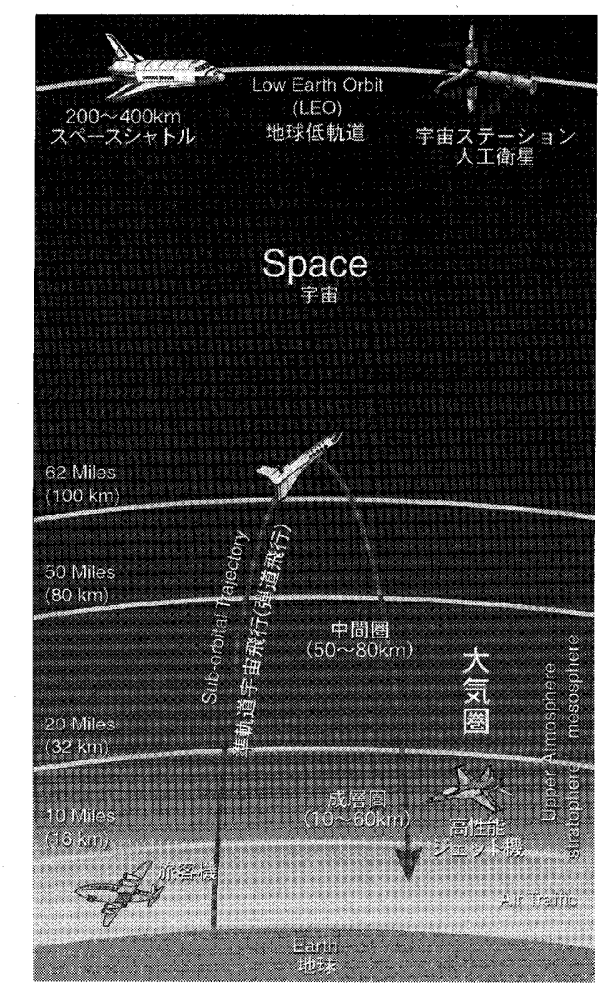

写真 3 弾道飛行による宇宙旅行イメージ (画像提供 : スペースアドベンチャーズ)

各社が弾道宇宙機を早く完成させたい理由はシェア確保 の他にもう一つある。現在は弾道飛行による宇宙旅行が計 画の中心だが、近い将来には周回軌道での宇宙旅行にシフ トするからだ。

技術的にみてもそれは当然の流れである上、Xプライズ 財団は周回軌道を回る宇宙機の賞を新設したのだ。

弾道飛行では見ることのできる地球の風景は限られ、同 じ場所に帰ることなる。周回宇宙旅行が実現すれば、地球 上の好きな場所を見ることができるようになる。航空機よ りも遥かに高速で旅客運行、物流ができるようになる。こ の結果、弾道宇宙旅行の需要はとても小さくなる。

これらから、弾道宇宙機開発に手間取ったり、これでよ しとして立ち止まっていることは企業の存続を危うくさせ ることになる。かといって、市場が熟成してから開発を開 始するのでは基礎開発で遅れをとり、基本特許を押さえら れ、何もできなくなる。
技術経営の観点で見るなら、弾道宇宙機製造をいち早く 事業化し開発資金を回収、次の周回軌道宇宙機の開発資金 確保と投資家の信任を得なければならない。メ一カーにと っては死の谷と呼ばれる厳しい状況との戦いとなるが、周 回軌道の市場は弾道飛行の比ではないので、これを超える ことで企業は大きな果実を手に入れることが出来る。

旅行用宇宙機が大型化してくると航空機と同じく部品や サブアセンブリの製造で日本に目が向けられるだろう。日 本メーカーは宇宙機そのものの開発は現在行っていないが、 いち早く行動し、部品で既に実績を上げている所もある。

また、宇宙旅行は宇宙機だけでなく宇宙港の建設も必要 となる。現在、世界各地で宇宙港の計画、建設が進められ ており、日本でも構想が練られている。

業界として事業が軌道に乗った後も各企業は生き残り戦 略が必要になるだろう。自動車や航空機産業をみても分か るように、草創期の大発展を終えた後は大多数の企業、名 門といわれていた企業ですら吸収、合併、消滅といった再 編の波に飲み込まれているのだ。

\section{4. 宇宙旅行事業の展望}

2006 年 11 月時点ではスペースアドベンチャーズが JTB と提携、ヴァージンギャラクティックがクラブツーリズム

（株）と提携し、日本での宇宙旅行販売空口を持っている。

費用は弾道旅行が $\$ 100,000 〜 \$ 200,000$ とまだ高価ではあ るが豪華客船の世界一周旅行並みとなった。

また、旅行者は安全上のリスクがあることを十分に認識 する必要がある。宇宙旅行用の保険はまだ存在せず、これ を了承することが宇宙に行ける条件の一つとなっているか らである。リスクは乗客だけでなく事業者にも言えること である。宇宙旅行ではまだ事故は未経験で、どのような影 響があるか分からないのだ。

宇宙旅行が事業として成立するためには一定の顧客の継 続的存在が必要不可欠である。幸いこちらは多くの予約者 で埋まっているそうで、しばらくは持ちそうである。ただ し、継続的に顧客を存在させるためにはマニアによる少数 者から一般の大多数に顧客の層を移さなければならない。

いずれ宇宙旅行は多くの人が利用するようになり顧客が 一巡する。そして宇宙旅行の希少価值が薄れる時が来る。 それでもなお宇宙旅行は航空機や船、場合によっては鉄道 と張り合えるだけの魅力と利便性を備えていなければなら ない。それができて初めて宇宙旅行は本当に一般化したと 言えるだろう。

\section{5.おわりに}

一般の宇宙旅行はもはや技術の問題ではなく、事業化の 問題となりつつある。今は先に目をつけ、先に実用化した 者が利益を取れる時だ。

メーカー、事業者、顧客共に乗り越えなければならない ハードルはまだまだあるものの、我々は、近くの旅行会社 に行って宇宙旅行を申し込むことが出来る時代に立ち会っ ているのだ。

参考文献 *1エリック・アソダーツ：宇宙旅行ハドブック、文芸春秋、2006 


\section{イベント報告}

\section{スペース・エンジニアリング・コンファレンス[SEC' 05]報告}

東京工業大学 古谷 寛

宇宙工学部門が企画するスペース・エンジニアリング・コンフ アレンスが、2005年 12 月 16 日 (金)に日本機械学会会議室で開催 された。本講演会は 2005 年 2 月に H2A ロケット 7 号機が 1 年 3 カ月ぶりに打ち上げに成功するなど、日本の宇宙開発も明るさが 見え始めた時期ということもあり、今後の日本の宇宙開発につな がる萌芽から応用研究にわたる幅広い領域の研究発表について、 十分な時間をとって議論することを目的としていた。

今年度の場合、諸般の事情により従来の開催時期に比べて 1 力 月程早く開催することになり、時期的にも年末と言うこともあり、 会員の皆様に多くの講演申込をしてもらえるか心配させられた が、例年より少し少ないものの 12 件の研究発表申込を集めるこ とができた。

講演内容としては、ロケット・衛星関係の研究として、大型展 開アンテナの構造設計法、技術試験衛星のラジエータ開発、衛星 搭載ロボットアームの検討、膜タンクの振動試験研究、などの研 究成果が発表された。また、将来の惑星間航行として世界的にも 実証に関心が集まっているソーラーセイルに関連して、展開膜面 のリアルタイム制御、ソーラーセイル膜面のスピン展開の実験研 究について報告がなされた。その他、形状可変トラスの追従運動 のための部材配置、構造振動モードに関する基礎研究、GPSによ る波浪計測など、今後宇宙開発で必要とされる要素技術ならびに 現在の宇宙技術の応用などの研究発表が行われた。

今回の講演会ではシステムならびに構造分野関係の発表が主 となって、推進や流体分野の発表が少なかった。これは講演時期 との兼ね合いではないとも考えられ、次回以降の課題となったと 言える。しかしながら、各講演発表時間を質疑を入れて 30 分と したことにより、通常の講演会よりも深 議論を行うことができ、 充実した講演会とすることができたと考えられる。

\section{宇宙工学講座「宇宙から日本を見よう！」報告}

山口大学 小河原 加久治

2006 年 8 月 9 日 (水)、山口大学工学部工学部図書館インフォ メーションルームにおいて、山口大学工学部機械工学科計測情報 工学研究室が航空宇宙学会西部支部との協賛により宇宙工学講 座「宇由功日本を見よう!」を開催した。受講者は一般公募に より中学生から成人までの8名、半日の講座であった。

講座は 3 部から構成され、第 1 部では田中佐教授が人工衛星の 構造と働き、ロケットによる打ち上げについて講義を行った。第 2 部では樋口丈浩助手が地球観測衛星から観測されたデータにつ いて、その構造と処理プログラムの概要を講義した。第3 部では 航空宇宙開発研究機構提供の地球観測衛星「大地 搭載の高分解 能可視近赤外放射計一II（AVIR-II）による山口地方の 4 波長デ 一タを処理し、受講者の望む画像を作成する演習を行った。作成 された山日地方の衛星画像を評価し受講者 2 名を表彰し宇宙工学 講座を終了した。

\section{綟集後記}

宇宙旅行関係者や大学衛星開発者たちと話をすると、彼らの 強、情熱伝わってくる。かつてオーヴィル・ライトは飛行機 の発明中、いわ夜明けが待ち遠しかったと語ったそうだ。こ の言葉に込めた思いを彼らは共有しているのだろう。

（三菱スペース・ソフトウエア (株) 横井 貴弘)
本講座は宇宙開発或いは宇宙技術が一般の人に縁皦いものと感 じられていると考え、宇宙技術を身近なものにする意図で実施さ れた。題材として人工衛星による地球観測をとりあげたのはこう した意四に沿った。地球画像は広く流通しているものの自分のア イデァによって自由に画像作成ができることを実感することは 宇宙技術を身近なものにするには最も適している。実際にデータ 処理に使ったアプリケーションプログラムは市販されている最 も一般的なものである。ただ衛星からの放射量データは一般の人 には入手は難しい。講座が終了し受講者は宇宙技術の一端に自ら 触れたことに概わ満足しているように見受けられた。

データ提供された航空宇宙開発研究機構の関係者の方々、演習 にチュータを務められた計測情報研究室のダッシュ助手、大学院 生、卒論生の協力があったことことを最後に記す。

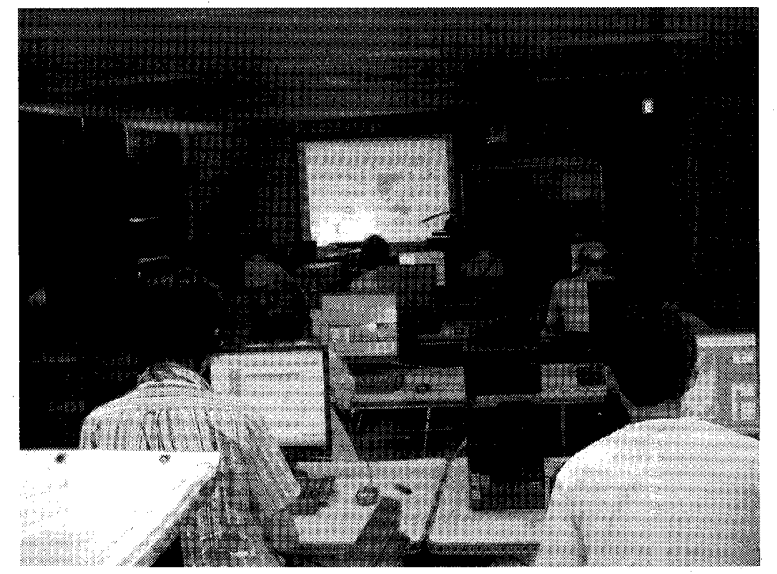

写真 1 宇宙工学講座風景

\section{THE FRAKK J. MALINA ASTRONAUTICS MEDAL 受賞}

(編集部)

1992 年に本部門の部門長をなされ、衛星設計コンテスト設立の 立役者となられました八坂教授 (現、九州大学) がこのほど、The Frank J. Malina Astronautics Medal という宇宙教育に関わる 世界的な賞を受賞されました。受賞に際して八坂教授から当部門 宛のメッセージをいただきました。

1992 年に当学会から他の 2 学会に声をか计た企画がその後大き く発展しました。機械学会、航空宇宙学会、電子情報通信学会が 始めた「衛星設計コンテスト」です。当時は、宇宙の「Hands-on」 大学教育では、欧米やアジアの近隣諸国にも先を越されていまし た。幸いこのコンテストは多くの大学に人工衛星を企画し設計 する機会を提供することとなりました。そこで培われた実力が、 その後の CanSat や CubeSat へと発展する原動力となり、現在の UNISEC を中心とした宇宙教育の定着につながったわけです。若者 たちの既成概念にとらわれない宇宙プロジェクトは、ろいろの 地域での宇宙活動を刺激しています。さらには、国全体の宇宙計 画にもよい影響を与えてゆくものであろうとおもいます。

(九州大学 八坂 哲雄)

2006 年も、日本の宇宙にとって怒涛の 1 年であった。 1 月か ら11月までに、H-IIA ロケット3機、M-Vロケット2機と合計 5 機の連続成功を達成。M-V の引退勧告。H-IIA ピギーバック衛 星公募の開始。12月にはH-IIA もう1機打上予定。宇宙活動の 転換期として記録されるであろう。

(東京工業大学 松永 三郎) 